\title{
Microbiological analysis of root canal space prepared for prosthetic intracanal posts
}

\section{Análise microbiológica do espaço do canal radicular preparado para pinos protéticos intracanal}

\section{Análisis microbiológico del espacio del conducto radicular preparado para postes intracanal protésicos}

\author{
Mauricio Aguirre ${ }^{1}$ \\ Eduardo Antunes Bortoluzzi \\ José Carlos Rivas Gutiérrez ${ }^{2}$ \\ Ronaldo Souza Ferreira Silva ${ }^{3}$ \\ Karina Maria Salvatore Freitas \\ Antonio Carlos Pizzolito ${ }^{4}$ \\ Fábio Luiz Camargo Villela Berbert \\ 1 mauroaguirrek@gmail.com \\ 2 jc.rivas@coop-atahualpa.com \\ 3 ronaldo@oralmasterlondrina.com.br \\ 4 Falecido. \\ Endereço para correspondência: \\ Karina Maria Salvatore Freitas \\ Centro Universitário UNINGÁ \\ Departamento de Ortodontia \\ Rodovia PR 317, 6114 \\ 87035-510 - Maringá - Paraná - Brasil \\ E-mail: kmsf@uol.com.br
}

Recebido: 26.08.2020

Aceito: 08.09.2020

\begin{abstract}
The aim of the study was to microbiologically analyze the root canal space prepared for prosthetic intracanal posts. Thus, a $2 \%$ chlorhexidine solution was used after the intraradicular preparation of ten teeth with endodontic treatment performed for prosthetic purposes and pulp vitality history. Two collections were performed for microbiological analysis: one before the use of the studied solution, showing positive microbiological culture in all cases; and another, after application for 3 minutes of $2 \%$ chlorhexidine solution. The results showed the effectiveness of the solution in nine of ten cases, presenting negative results in microbial culture.
\end{abstract}

KEYWORDS: Endodontics. Dental leakage. Dental pins. 


\section{RESUMO}

O objetivo do estudo foi analisar microbiologicamente o espaço do canal radicular preparado para pinos protéticos intracanal. Assim, foi utilizada solução de clorexidina a $2 \%$ após o preparo intraradicular de dez dentes com tratamento endodôntico realizado para fins protéticos e histórico de vitalidade pulpar. Foram realizadas duas coletas para análise microbiológica: uma antes do uso da solução estudada, evidenciando cultura microbiológica positiva em todos os casos; e outra, após aplicação por 3 minutos da solução de clorexidina $2 \%$. Os resultados mostraram a eficácia da solução em nove dos dez casos, apresentando resultados negativos na cultura microbiana.

PALAVRAS-CHAVE: Endodontia. Infiltração dentária. Pinos dentários.

\section{RESUMEN}

El objetivo del estudio fue analizar microbiológicamente el espacio del canal radicular preparado para los postes intracanal protésicos. Así, se utilizó una solución de clorhexidina al 2\% luego de la preparación intrarradicular de diez dientes con tratamiento endodóntico realizado con fines protésicos y antecedentes de vitalidad pulpar. Se realizaron dos recolecciones para análisis microbiológico: una antes del uso de la solución estudiada, mostrando cultivo microbiológico positivo en todos los casos; y otro, después de la aplicación durante 3 minutos de una solución de clorhexidina al 2\%. Los resultados mostraron la efectividad de la solución en nueve de diez casos, presentando resultados negativos en cultivo microbiano.

PALABRAS CLAVE: Endodoncia. Filtración dental. Pins dentales. 


\section{INTRODUCTION}

For the success of an endodontic treatment, it is extremely important the most hermetic sealing of the root canal so as to prevent its infection or reinfection in cases of vitality or pulp necrosis, respectively.

Any procedure performed inside the root canal after its obturation should be carefully performed so as not to break the aseptic chain that is essential for the favorable prognosis of endodontic treatment.

Studies have proven the vulnerability of the filling material to cervical-apical root canal infiltration when exposed to: microorganisms, dyes, radioactive markers, and pressure fluid ${ }^{1-4}$, therefore, care must be taken.

Clinically, this exposure occurs when, after the endodontic treatment, the coronary and/or cervical aspect of the tooth is not properly sealed. The absence of adequate restorative material in this region, as well as restorations with insufficient sealing of the tooth-restorative material interface become an access way for buccal fluids to the obturated root canal.

The situation becomes even more critical when it is necessary to partially remove the filling material present in the root canal to make space for the prosthetic posts. Thus, exposure of the obturator material to buccal fluids may occur at the moment when the endodontically treated root canal is partially unblocked and prepared to the proper size and shape to receive the prefabricated pin or during modeling of the pin matrix to be fused, as well as at the time of making the provisional crown and also for its inadequate adaptation. In clinical situations, this exposure occurs due to the absence of absolute isolation, since the use of the rubber dam is not always possible due to the lack of coronary structure.

Some authors, concerned about this issue, suggest maintaining aseptic techniques during posts preparation, root canal irrigation, and the use of intra-canal medication such as calcium hydroxide paste between the pin preparation and shaping session and the cementation session ${ }^{1,4-5}$. Hence the importance of the temporary cement used has efficient physicochemical properties that do not to allow root canal contamination.

Chlorhexidine solution in different concentrations, in the form of salt, whether gluconate, acetate or hydrochloride, has been used as mouthwash in the form of mouthwash, gels, dentifrices or chewing gum since the $1950 \mathrm{~s}^{6}$.

In endodontics, chlorhexidine has been used as a root canal irrigating solution due to its peculiarities. Their broad spectrum of action against gram-positive and gramnegative bacteria, their prolonged gradual effectiveness at therapeutic levels (substantivity), and their biocompatibility are characteristics that justify its clinical $u^{7-8} \mathrm{f}^{7.8}$. Thus, the use of this solution among the clinical procedures of preparation and cementation of the prosthetic posts seems very timely.

This study aims to perform, in vivo, a microbiological analysis of root canal space contamination prepared for placement of prosthetic intracanal posts, before and after the use of $2 \%$ chlorhexidine solution.

\section{MATERIAL AND METHODS}

Participated in this study patients of both genders, with good overall health; submitted to prosthetic dental treatment.

The patients' clinical records were analyzed and 10 teeth were selected, with a clinical history of endodontic treatment in vital teeth, that is, for prosthetic purposes. In addition, only cases intended to prepare for prefabricated pin placement in a single session were selected.

Then, a clinical protocol for obtaining and collecting microbiological was followed, so that the aseptic chain was respected, not interfering with the results. Thus, it was sought to respect all clinical procedures that are normally performed in one session for placement of a prefabricated prosthetic intracanal post.

Such protocol is detailed below:

1. The places where the research material was collected were the Prosthesis Clinics.

2. Patient records were checked to see which endodontic treatment received the tooth in question, and the time since the endodontic treatment was completed; Only teeth whose endodontic treatments had been performed at most one month before the collecting were selected.

3. Evaluation of the clinical conditions of the dental element to be treated: unsealed; with temporary sealing (observe infiltration); with provisional crown (observe adaptation). Only teeth that clinically showed no signs of infiltration, decay or maladaptation of the temporary crown and/or sealing with temporary cement were selected.

4. Clinical tweezers and 70 gauge absorbent paper cones (Tanari Industrial Ltda., Manaus, Brazil), both sterilized in autoclave (Dabi Atlante, Ribeirão Preto, Brazil), were used for microbiological collections. For sterilization, the cones were packed in clean glass bottles, covered with a cotton ball.

5. After the professional prepared the canal and when the canal was ready for pin placement, the sterile saline was washed and the excess was removed with an endodontic sucker. At this moment, the "first collection" of the research material was performed, which consists of dragging a paper cone against all the root canal walls (Figure 1), reaching all prepared length, taking the collected material to be sown in the thioglycolate culture medium, which supports the growth of a variety of demanding microorganisms (Figure 2). 


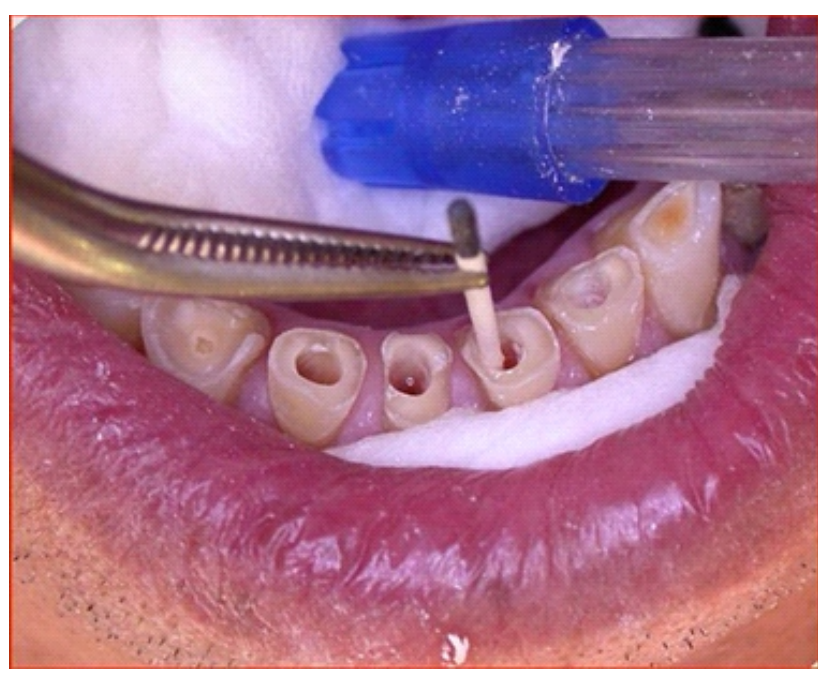

Figure 1 - First collection of the material in the root canal.

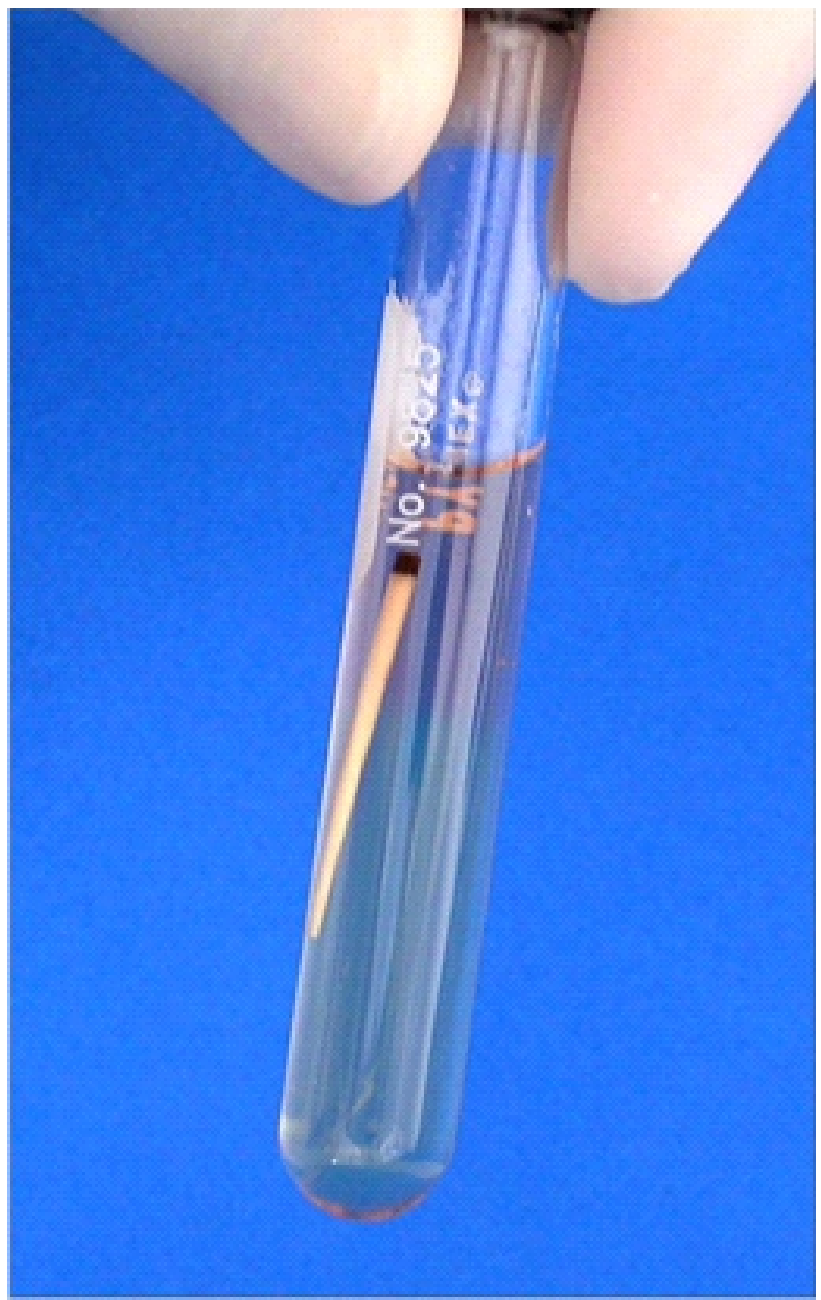

Figure 2 - Material collected sown in the thioglycolate culture medium.
6. After the first collection, the root canal was filled with $2 \%$ chlorhexidine solution by means of a syringe with a sterile needle $(10 \mathrm{~mL}$ Luer syringe and $30 \mathrm{X} 5$ hypodermic needle). The chlorhexidine was left inside the root canal for 3 minutes.

7. After the allotted time, the canal was washed with sterile saline and the excess removed with endodontic suction. At this moment the "second collection" of the research material was carried out, which consisted of dragging a paper cone on all the root canal walls, reaching all the prepared length, taking the collected material to be sown in the culture medium mentioned above. Between the two cones, the tweezers were buckled in the flame of a lamp.

8 . With the dry canal, the professional continued the treatment by cementing a prefabricated pin.

To perform the collecting, the root canal must necessarily be moist; For this reason, excess saline (first and second collection) was removed with the endodontic sucker, while the root canal remained moist.

The material from both collections, stored in thioglycolate, was left in a heated chamber at $37^{\circ} \mathrm{C}$ for 24 hours. After the incubation period, the thioglycolate solution was closely observed to identify signs of turbidity. Turbidity meant bacterial growth. All culture media, even those that have not turbid, have undergone biochemical tests to identify the predominant bacterial genus and species.

\section{RESULTS}

The result of the microbiological analysis showed that:

1. There was previous contamination in all cases analyzed at the time of the first collection (Table 1).

2 . The predominant bacteria were Enterococus faecalis and Streptococcus viridans.

3. After the use of $2 \%$ chlorhexidine solution for three minutes before the intraradicular pin cementation, that is, before the second collection, the presence of microorganisms inside the intracanal root preparation was negative in nine samples, according to Table 1.

Table 1 - Results of the microbiological test. Presence (+) or absence (-) of bacterial growth after the 1 st and 2 nd collection on each tooth.

\begin{tabular}{ccccccccccc}
\hline Tooth & 1 & 2 & 3 & 4 & 5 & 6 & 7 & 8 & 9 & 10 \\
1st collection & + & + & + & + & + & + & + & + & + & + \\
2nd collection & - & - & - & - & - & - & - & - & - & +
\end{tabular}




\section{DISCUSSION}

The microbiota present in the root canals was found after the preparation for placement of an intra-canal pin, and this microbiota would be related to its action only in the root canal light and adjacent dentin mass.

Thus, for this preparation to cause a decrease in the microbiota present in the root canal, it should be associated with an irrigating solution capable of having some bactericidal and/or bacteriostatic effect on the microorganisms present in the root canal light, and adjacent dentin. As, clinically, such preparation is done only under water cooling, such decontamination does not occur. Thus, it became feasible to study and use a solution that is proven to have action against microorganisms present in the root canal.

It is worth remembering that the root canal communicates with the periodontium through the main foramen, apical delta, accessory, lateral and secondary canals. Thus, the presence of ramifications at any height of the root facilitates communication between the root canal and the periodontium ${ }^{5}$. Microorganisms and their products can infiltrate these access ways and reach the periodontium, causing inflammation in the periapical tissues, making root canal retreatment or periapical surgery necessary ${ }^{9}$.

This clinical situation is of great importance because in vitro studies show that microorganisms, radioactive markers, and pressurized fluids, when placed in the cervical region of pin-prepared teeth, reach the periapex more frequently and faster than when the root canals are not prepared for intracanal root posts, ${ }^{4,10-11}$.

Therefore, a care protocol should be inserted during the prosthetic preparation of the root canal for the installation of intracanal posts, with the greatest possible care to avoid contamination of this root canal, leading to possible posterior endodontic failure.

In addition, it should be emphasized the coronary sealing between sessions, which should be performed with a provisional obturator cement that meets the basic physicochemical requirements, without morphological changes after setting and being resistant to chewing efforts, supporting the time required for following session, as well as the confection of a well-adapted provisional crown, which prevents the contamination of the root canal. We verified in this study the previous contamination in all cases analyzed at the time of the first collection. This probably occurred due to infiltration at the temporary cement/tooth interface; or due to maladaptation of the provisional crown, although not clinically detected, assuming that the aseptic chain should be maintained while performing the biopulpectomy previously performed. According to AbouRass $^{12}$ it is imperative that endodontic foundations be as solid as possible when a tooth is indicated as a pillar for extensive rehabilitation.
The chlorhexidine solution, considered as a cationic bisguanide, has antimicrobial action, being active against gram-positive and gram-negative microorganisms, spores, lipophilic viruses, blastophils and dermatophils, with bacteriostatic action at low concentrations and bactericidal at higher concentrations ${ }^{13}$. It was suggested as an endodontic irrigating solution or even delay curative $\mathrm{e}^{14}$.

Several authors confirm the in vitro activity of chlorhexidine against microorganisms involved in endodontic infections ${ }^{14-15}$ including E. faecalis ${ }^{16-18}$.

This study corroborated with the above and showed that chlorhexidine is effective for disinfection of the prepared root canal because it eliminated gram-positive bacteria, Enterococus faecalis and Streptococcus viridans, which are facultative anaerobic cocci normally found in necrotic pulps. In addition, chlorhexidine solution has satisfactory biological properties ${ }^{19-20}$.

\section{CONCLUSION}

The conditions under which the experiment was conducted as well as the methodology employed allowed us to conclude that:

1. The use of $2 \%$ chlorhexidine solution after canal preparation for placement of an intracanal post is a viable clinical procedure due to the decontamination provided by it.

2. Further studies should be conducted to examine whether this solution would have the same bactericidal power in endodontically treated teeth with a history of previously treated pulp necrosis as well as teeth that have remained with temporary cement and/or crowns for more than one month before the prosthetic preparation.

\section{REFERENCES}

1. Siqueira JF, Lopes HP. Endodontia: biologia e técnica. Rio de Janeiro: Medsi; 1999.

2. Timpawat $\mathrm{S}$, Amornchat $\mathrm{C}$, Trisuwan WR. Bacterial coronal leakage after obturation with three root canal sealers. J Endod. 2001;27:36-9.

3. Trope M, Chow E, Nissan R. In vitro endotoxin penetration of coronally unsealed endodontically treated teeth. Endod Dent Traumatol. 1995;11:90-4.

4. Wu MK, De Gee AJ, Wesselink PR. Fluid transport and dye penetration along root canal fillings. Int Endod J. 1994;27:233-8.

5. Só MV, Manfro A, Limongi O. A proposal for temporary sealing of the channel space prepared to receive an intra-radicular nucleus. Stomatos. 1998:37-40. 
6. Denton GW. Chlorexidine. In: Denton GW, Block SS, editors. Desinfection, sterilization and preservation. Philadelphia: Lea \& Fabiger; 1991.

7. Jenkins S, Addy M, Wade W. The mechanism of action of chlorhexidine. A study of plaque growth on enamel inserts in vivo. J Clin Periodontol. 1988;15:415-24.

8. Rolla G, Loe H, Schiott CR. Retention of chlorhexidine in the human oral cavity. Arch Oral Biol. 1971;16:1109-16.

9. Alves J, Walton R, Drake D. Coronal leakage: endotoxin penetration from mixed bacterial communities through obturated, post-prepared root canals. J Endod. 1998;24:587-91.

10. Abramovitz I, Tagger M, Tamse A, Metzger Z. The effect of immediate vs. delayed post space preparation on the apical seal of a root canal filling: a study in an increased-sensitivity pressure-driven system. J Endod. 2000;26:435-9.

11. Mallmann J. Avaliação da infiltração cérvico-apical, através de canais obturados por técnicas da guta-percha termoplastificada e condensação lateral, após o preparo do espaço para retentor intraradicular: estudo in vitro [dissertation]. Florianópolis (SC): Universidade Federal de Santa Catarina; 1997.

12. Abou-Rass M. The problems with "wait and see" endodontics. J Calif Dent Assoc. 1993;21:43-7.

13. Leonardo MR, Tanomaru Filho M, Silva LA, Nelson Filho P, Bonifacio $\mathrm{KC}$, Ito IY. In vivo antimicrobial activity of $2 \%$ chlorhexidine used as a root canal irrigating solution. J Endod. 1999;25:167-71.

14. Delany GM, Patterson SS, Miller CH, Newton CW. The effect of chlorhexidine gluconate irrigation on the root canal flora of freshly extracted necrotic teeth. Oral Surg Oral Med Oral Pathol. $1982 ; 53: 518-23$.

15. Jeansonne MJ, White RR. A comparison of $2.0 \%$ chlorhexidine gluconate and $5.25 \%$ sodium hypochlorite as antimicrobial endodontic irrigants. J Endod. 1994;20:276-8.

16. Almyroudi A, Mackenzie D, Mchugh S, Saunders WP. The effectiveness of various disinfectants used as endodontic intracanal medications: an in vitro study. J Endod. 2002;28:163-7.

17. Komorowski R, Grad H, Wu XY, Friedman S. Antimicrobial substantivity of chlorhexidine-treated bovine root dentin. J Endod. 2000;26:315-7.

18. Orstavik D, Haapasalo M. Disinfection by endodontic irrigants and dressings of experimentally infected dentinal tubules. Endod Dent Traumatol. 1990;6:142-9.

19. Oncag O, Hosgor M, Hilmioglu S, Zekioglu O, Eronat C, Burhanoglu D. Comparison of antibacterial and toxic effects of various root canal irrigants. Int Endod J. 2003;36:423-32.

20. Yesilsoy C, Whitaker E, Cleveland D, Phillips E, Trope M. Antimicrobial and toxic effects of established and potential root canal irrigants. J Endod. 1995;21:513-5. 